Tanzania and Uganda, the members of the former East African Community, and his success in settling differences between the parties won him the esteem of all concerned.

Victor Umbricht's exceptional abilities as mediator were tremendously useful to the Red Cross Movement in furthering its specific objectives of bringing help and protection to the victims of war. It can thus be said that thousands of men and women throughout the world benefited from his work.

In a tribute to the former Vice-President, Cornelio Sommaruga, President of the ICRC, said: "Victor Umbricht devoted himself to the Red Cross with steadfast optimism, unflagging energy and unfailing dedication.... Victor Umbricht was a true citizen of the world who did not take lightly his position as member of the International Committee. He passionately believed in the ICRC's objectives and strove to ensure that the institution remained faithful to his own principles of total competence, flexibility, discretion and non-paternalistic tolerance.... His hopes and objectives remain our own. We are profoundly indebted to him for the example he set ... and shall do our utmost to follow in his footsteps."

\title{
Death of Professor D. Frei member of the ICRC
}

Daniel Frei, member of the International Committee of the Red Cross since 1 March 1986, died suddenly on 1 August 1988.

Dr. Frei was born on 24 October 1940 in St. Gallen. When he was 24 years old, he obtained a doctorate in history from the University of Zurich. His studies took him to the London School of Economics and Political Science, the University of Michigan and finally the Graduate Institute of International Studies in Geneva where he received a degree in 1967.

In 1968 he became a lecturer and in 1971 Professor of Political Science at the University of Zurich. He was also Director of the Swiss Institute for International Research.

Dr. Frei was the author of many publications dealing with East-West relations, disarmament, neutrality and international co-operation. He 
was a member of the Club of Rome and consultant to UNITAR (United Nations Institute for Teaching and Research) and UNIDIR (United Nations Institute for Disarmament Research).

He believed fervently in our cause and devoted himself to it throughout his time as member of the ICRC, placing his vast knowledge at the service of the Movement.

Dr. Frei belonged to several ICRC committees, including those responsible for principles and general policy and relations with the other components of the Movement. He was also a member of the working groups for the ICRC's "Plan for the future", public relations and the Clark R. Benedict Fund. He served on the Commission on the Red Cross, Red Crescent and Peace and in that Commission's working group on human rights. Finally, he was a member of the ICRC's delegation to the Twenty-fifth International Conference of the Red Cross in 1986.

Dr. Frei carried out missions for the ICRC in Turkey, Jordan, Romania, Poland, French Guiana, Brazil, the United States, Bulgaria, Italy and Israel. He was about to become a member of the General Assembly of the Henry Dunant Institute.

The Committee is profoundly grateful for Dr. Frei's devoted work and deeply distressed by his premature death. 